\title{
Nothing New Under the Sun: The Development of Habeas Corpus and Executive Power in the Bush Administration
}

\author{
Justin J. Wert
}

This article details the origins of the Bush administration's policies with respect to executive power and access to the writ of habeas corpus. I argue that the administration's policies devised to prosecute the "War on Terror" were simply extensions of already developing patterns of conservative legal and constitutional theory. This account suggests that as an "Orthodox Innovator" president, it is likely that President Bush's particular developments and additions to this larger regime stance went too far to continue to remain legitimate, but not in the way that the literature suggests. As a result of the Bush presidency, then, dissent is more likely to come from the judiciary and not the party faithful.

Very few presidential administrations have been marked by as many extraordinary political developments as that of George W. Bush. Even before he took the Oath of Office, Bush was at the center of the most contested presidential election since Rutherford B. Hayes was handed the presidency over Samuel Tilden in 1876 in exchange for ending Reconstruction in the South. And to many observers, both scholarly and journalistic, the Rehnquist Court likewise did the same in Bush v. Gore. ${ }^{1}$ Soon after taking office, the Bush administration was again at the center of constitutional controversy, this time with respect to Vice President Dick Cheney's refusal to allow records to be released from the National Energy Policy Development Group which he chaired. ${ }^{2}$ But the most salient developments are of course those that have precipitated from the terrorist attacks on September 11, 2001 and the subsequent proclamation of a "War on Terror." From warrantless wiretaps to domestic spying to the rendition of terrorist suspects to the redefinition of torture itself, the Bush administration has easily taken its place as one of the most constitutionally important—and controversial—in American history.

What has made these political and constitutional developments seemingly unique is that, for the most part, they have been the products of war and not of the day to day utilization of executive power. From a normative perspective it is undeniably fortunate that we have not had to engage in armed conflict as much as other nations have. ${ }^{3}$ From a theoretical perspective, this means that important constitutional questions related to war have not allowed for the creation of large databases or numerous case studies

JUSTIN J. WERT is an assistant professor of political science at the University of Oklahoma.

The American Review of Politics, Vol. 29, Winter, 2008-2009: 273-289

(C)2008 The American Review of Politics 
which would facilitate more sophisticated analyses of the relationship between war and constitutionalism more generally. But this does not mean that there has been a dearth of literature that has sought to make sense of the presidency's relationship to war and constitutionalism, for there has. This literature, though, is characterized by an almost universal assumption that the extraordinary events of war and crisis produce political, legal, and constitutional environments that are so different from peace-time politics that comparison becomes extremely difficult at best, or naïve at worst (Rehnquist 1998; Rossiter 2002; Tushnet 2005). The potential continuities between wartime and peace-time politics, particularly with respect to theories of executive power, are thus often left unexamined.

When we study the relationship between the presidency and war, then, the problem becomes even more difficult. As with the paucity of data for war, the study of the presidency - unlike that of the Congress, for exampledoes not easily yield itself to large- $N$ analyses, simply because we have had so few presidents. Moreover, traditional theories of presidential leadership, like those advanced by Richard Neustadt, become even more problematic if interrogated through the lens of war. Even if we were to accept Neustadt's formula for presidential leadership in the post WWII years, which lays out a model of effective governance within an administrative state during peacetime, it would seem that war's exceptionalism would preclude its usefulness if we continue to envision war as an exogenous shock to the polity that creates wholly new political and constitutional problems. Without more nuanced models, then, we are left with very few analytical tools to understand developments, changes, and continuities within a presidential administration like that of George W. Bush.

Fortunately, we now have relatively plausible theories for both the study of the presidency and the presidency's role in creating political development during war or crisis, though, to date, these two approaches have not been sufficiently exploited. Stephen Skowronek's (1997) interrogation of the presidency through the lens of historical institutionalism has pushed the data-poor extant models of presidential studies to re-evaluate their idiosyncratic and time-bound analyses. The variable of "time" has now taken its place alongside familiar short-term variables such as character (Orren and Skowronek 2004; Barber 1992). Similarly, in the field of war-time constitutionalism, scholars are also asking temporal questions about longer-term developmental patterns that might help elucidate answers to such counterintuitive questions as why rights might actually increase during war (Klinker and Smith 2002; Dudziak 2000; Graber 2005a, 2005b). With time as a meaningful variable, we are now able to theorize about patterns or periodizations of war-time presidencies in ways that make them more portable and 
generalizable. In a small way, this type of analysis would allow us to overcome the shortfalls of both war-time and presidential studies.

In this vein, I lay out an account of the origins and development of the Bush administration's war-time policies with respect to the increase of executive power and the application of the writ habeas corpus for enemy combatants, two of the most controversial aspects of the Bush presidency. I argue that while the Bush administration certainly faced a significant exogenous shock in the form of the terrorist attacks of September 11, 2001, the policies devised in reaction to the event were not wholly new (see also Zelizer 2008). As I will show, the Bush administration's understanding and use of executive power were mostly extensions and modifications to the Republican party's larger legal and constitutional agenda that had already been developing at least since the presidency of Richard M. Nixon. In partial agreement with Skowronek's (1997) notion of “Orthodox Innovator” presidents, I argue that it is likely that the Bush administration's particular developments and additions to this larger regime stance went too far to continue to remain legitimate and authoritative, but not in the way that Skowronek suggests or even believes is the case for the Bush presidency. Instead, because the Republican party's defining features over the last forty years have largely been couched in legal terms, dissent is more likely to come from the judiciary and not the party faithful. This suggests that, at least with respect to habeas corpus development and more general notions of executive power, conservatives are showing signs of significant divergence within the judiciary, and future Republican executives will not be able to rely as easily on older justifications for decreased habeas access and unilateral executive power as they had during the height of Republican power.

The article is divided into three parts. First, I trace the development of the conservative reaction to increased habeas corpus access from the Warren Court to the Bush administration's most recent arguments in favor of habeas curtailment for enemy combatants. As I show, the administration's policies were simply extensions of already developing arguments designed to limit habeas in general. In the second part, I account for the development of conservative arguments in favor of increased executive power beginning with the War Powers Act (WPA) of 1973. ${ }^{4}$ The arguments advanced by conservative constitutional theorists since the WPA were not only welcomed in the Bush administration but were also extended and implemented. Finally, I suggest that the Bush presidency does in fact exhibit the characteristics of what Skowronek calls "Orthodox Innovator" presidents (1997; 2008). The deep intra-party divisions that normally befall these types of executives, though, are now coming from the Court and not the party faithful. Thus, I also call for a better integration of courts and party development in presidential studies. 


\section{The Development of Crime and Punishment: Habeas Corpus}

The Warren Court wrought many significant constitutional developments, including the now-ubiquitous Miranda warnings, the right to counsel famously announced in Gideon v. Wainwright (1963), the right to privacy, seismic changes in voting rights, and of course school desegregation. ${ }^{5}$ What was also wrought was a significant backlash by conservatives and an ascending Republican party of the late 1960's (Powe 2000). Particularly with respect to the Warren Court's criminal procedure and voting rights decisions, an identifiable political and legal counter-revolution began to take shape (Teles 2008).

Dissent from the Court's largesse had already been growing in academic legal circles since the beginning of the Warren Court, starting with Herbert Wechsler's classic formulation of "neutral principles" in Constitutional adjudication (Wechsler 1959). On the ground, the reaction to the Warren Court's habeas corpus jurisprudence of the early 1960's, which the Court reformulated to help enforce its criminal procedure revolution, came swiftly (Powe 2000). This backlash is nicely laid out in the Speedy Trial Act of 1971, which was one of President Nixon's attempts at curbing judicial power. Among its provisions, the Speedy Trial Act sought to ensure the Sixth Amendment's guarantee of a "speedy trial" by mandating changes in federal district court procedures. The most important change would have been the requirement of a sixty day maximum time period between charge and trial. Various witnesses were called to comment on the Bill before the Senate, but one witness, and his suggestions for making the bill stronger, stands out. On July 14, 1971, the Senate called then assistant Attorney General of the United States, William Rehnquist, to offer testimony on behalf of the Department of Justice. Rehnquist supported the bill in theory, but thought that as it stood it did not go far enough. What was needed was an additional measure in the bill that would also mandate reform of the existing rules governing habeas corpus. According to Rehnquist, the Sixth Amendment's guarantee of a speedy trial was most hampered by increased access to habeas corpus by state prisoners to federal district courts. His concerns about habeas jurisprudence as it had developed since the Warren Court were representative of larger conservative critiques: they prevented "finality" in criminal procedure adjudication and seemingly ignored the low probability of the "actual innocence" of the defendant, a charge that had been growing since Mapp v. Ohio and Miranda v. Arizona (Bator 1963; Friendly 1965). Moreover, habeas petitions had so clogged federal courts that in 1971 district courts received almost 11,000 habeas petitions. Rehnquist proposed that Congress change the existing habeas law according to the suggestions of Henry Friendly and Paul Bator, whose seminal law review articles he cited 
in his testimony, and who suggested that the actual guilt or innocence of the defendant, as well as concerns of finality in criminal adjudication more generally, should govern access to habeas. Habeas claims that relied on newly applied (or discovered) rights, like the Fourth Amendment's exclusionary rule, or misapplied Miranda rights (which only related to technical procedures and did not establish or suggest innocence) should be barred.

Rehnquist's reading of the historical development of habeas argued that the Warren Court had taken the minor habeas expansions in outlier due process cases in the beginning of the twentieth century, which increased habeas access during mob dominated and race-laden trials, and made them the rule for any and all constitutional challenges. ${ }^{6}$ In other words, the use of habeas to examine extraordinary trials with no due process whatsoever had transformed into a mechanism by which any state-level trial, no matter how perfect or seemingly free from error, could be questioned on any federal Constitutional ground, thus ultimately delaying conviction and preventing justice. He said of these types of early cases, "Hard cases make bad law.", At the end of his testimony to the committee, Senator Ervin engaged Rehnquist in a conversation about the Warren Court's most controversial rulings, Mapp v. Ohio and Miranda v. Arizona. After complaining that the Warren Court overstepped its duties in these cases, Ervin then agreed with Rehnquist that it had also overextended habeas. He said he had always admired Justice Jackson's opinion in Brown v. Allen, where, in describing the district court's flood of frivolous habeas opinions, Jackson said, "It must prejudice the occasional meritorious [habeas] application to be buried in a flood of worthless ones. He who must search a haystack for a needle is likely to end up with the attitude that the needle is not worth the search." ${ }^{8}$ Rehnquist said he remembered that portion of the argument very well because he was Jackson's clerk at the time he wrote his opinion. ${ }^{9}$

Rehnquist and the ascendant Republican party would not see formal congressional changes to habeas until 1996 when Congress passed the AntiTerrorism and Effective Death Penalty Act. With no legislative majority to make the changes (although there were bills presented almost every year for habeas reform), the Supreme Court was left to fashion its own changes to habeas jurisprudence in an effort to undo the Warren Court's habeas jurisprudence (Yackle 1982). If the Burger Court (and later Rehnquist's own Court) was to overturn and re-fashion a habeas jurisprudence that had been overstretched and manipulated by the Warren Court, they would have to guide the Court to a return to the pre-Warren Court understanding of habeas. In many ways, this is the path that the Burger and Rehnquist courts would follow until the 1996 AEDPA codifications (Federman 2004). This new vision, and the steps the Court, Congress, and the President would take to achieve these changes, developed into the habeas jurisprudence-and 
attempted statutory changes - that became the party line of the Republican party that George W. Bush would eventually lead.

And so the change began. Although the Burger Court never delivered completely on the changes that Nixon and the newly ascendant Republican party had desired, it did manage to curtail habeas in meaningful ways. The biggest change came in the form of a two-pronged attack on both habeas and the exclusionary rule announced in Mapp v. Ohio. In Stone v. Powell (1976), the Court ruled that exclusionary rule challenges that had already been fully and fairly litigated in state courts could no longer automatically trigger habeas appeals to federal district courts. And the Burger Court, including new additions like Justice Sandra Day O'Connor, would continue to chip away at the enlarged habeas rights that the Warren Court had created. ${ }^{10}$

As Larry Yackle has detailed, at least seven different bills from 1981 to 1982 between the House and the Senate were introduced that in some way sought to reform habeas corpus (Yackle 1982). For one bill, S. 2216, "The Habeas Corpus Reform Act of 1982,” Ronald Reagan's Attorney General, William French Smith, submitted a letter to the Senate detailing the administration's goals. While asserting that the administration was "firmly committed to the enforcement and protection of federal rights including the federal rights of criminal defendants in state proceedings," Smith went on to say that "there is no justification in the present day for the availability of federal habeas corpus as a routine means of review of state criminal convictions." 11 Smith's position for reforming habeas was justified by three arguments that all confirmed the administration's frustration with the Warren Court's habeas enlargement. His first argument was that many states had since reformed their appeal processes to reflect changed notions of due process, most likely as a result of the incorporation decisions of the Warren Court. Second, federal habeas had offended the "integrity of state procedures." And third, because state courts were "trustworthy expositors of federal law," they were fully capable of the task of vindicating and overseeing the protection of fundamental national rights. ${ }^{12}$

Although the bill never became law, the Reagan administration continued to argue for more limits to habeas. In 1988 the Department of Justice's Office of Legal Policy produced a report to the Attorney General detailing its suggestions for reform. ${ }^{13}$ Reading the historical function of habeas corpus much differently than the Warren Court had, the report argued that legislation should be enacted which returned habeas to its proper role in the federal system, further affirming the "dignity and independent stature of state courts" (Federman 2004, 324). The report even suggested the potential elimination of habeas altogether, arguing that its current use was only Congressionally determined and was therefore not constitutionally mandated. However, the report did suggest limitations in lieu of complete abolishment, 
including limiting appeals to one year time limits from state court conviction; more deference to state court's determinations of facts relating to alleged constitutional violations; and limits on habeas for Fifth and Sixth Amendment claims (Federman 2004, 325).

The same year as the DOJ report on habeas, Chief Justice William Rehnquist appointed former Supreme Court Justice Lewis Powell to lead the "Ad Hoc Committee on Federal Habeas Corpus in Capital Cases." The report of this committee, as well as Powell's published remarks to the American Bar Association the following year, made clear the frustration that was felt by some concerning the time-delays in death penalty cases that employed expanded habeas corpus appeals from state prisoners. Powell argued that the deterrent effects of the death penalty since Gregg v. Georgia, which allowed states to resume capital punishment, were stymied by habeas petitions in federal courts. ${ }^{14}$ He argued that "the evidence ... is compelling that a large majority of our people consider that capital punishment is appropriate for certain crimes" and that the delay in fulfilling this felt need stemmed from "our unique system of dual collateral review of criminal convictions," further buttressing conservative arguments related to habeas' impact on federalism (Powell 1989). According to Powell, Congress established this review in the 1867 Habeas Corpus Act, and the judiciary "federalized" the supervision of the death penalty as a result of its decision in Furman v. Georgia, by allowing federal constitutional challenges in almost all death penalty cases. ${ }^{15}$ One of Powell's proposed solutions-Congressional legislation that would impose a statute of limitations on habeas appeals-also provided for an exception for defendants who could not obtain "qualified counsel." Nevertheless, he continued to argue that habeas reforms were needed to speed up the time from prosecution to execution because of the "alarming murder rate that prevails in this country" (Powell 1989, 1044).

The American Bar Association's habeas reform proposals during the Reagan administration reflected some of Powell's suggestions, although not without important differences. The ABA's concerns about time-delays through habeas petitions came in the form of proposed legislation that would impose a statute of limitations on habeas appeals. The similarity to Powell's suggestions is seen in the ABA's concerns about inadequate representation of counsel for death penalty defendants. Their proposals advocated that states mandate specialized training and increased pay for death penalty attorneys who shouldered most of the burden of representation.

Republican efforts to chip away at enlarged habeas access would reach their apex in the form of The Anti-Terrorism and Effective Death Penalty Act (AEDPA) which became law on April 24, 1996. The AEDPA simply represented the codification of many of the restrictive habeas cases from the 
Burger and Warren Courts as well as the failed Congressional attempts to reform and, in some cases, completely eliminate, habeas access. The AEDPA had three salient components. First, it established a one year time limit for filing petitions from state to federal courts. Second, it cut out the "successive petitions" rule that had been previously developed by the Court, by allowing only one chance for federal review of constitutional challenges. Third, as the word "efficient" in the statute indicates, "A determination of a factual issue made by a State court shall be presumed correct. The applicant shall have the burden of rebutting the presumption of correctness by clear and convincing evidence."16 Although passed to help combat terrorism both at home and abroad (the AEDPA was passed in the wake of the bombing of the Alfred A. Murrah Federal Building in Oklahoma City), it represented a "wish list" of many habeas opponents in its codification of a more conservative, states' rights oriented philosophy that had been developing since the 1960's with respect to crime and habeas corpus jurisprudence more generally (Federman 2004, 323).

The Bush administration's position with respect to habeas corpus in the "War on Terror" is thus a simple extension of these already well-developed arguments. For example, in Boumediene v. Bush (2008), the most recent habeas case to come before the Court, Paul Clement, the United States Solicitor General, laid out three points of defense against the argument that the Military Commissions Act (MCA) violated the Constitution's suspension clause. The first objection was cast in the familiar rhetoric that argued that habeas had been so transformed over the last three decades that it now had the very real potential to tip the scales of justice in the favor of patently guilty defendants who, with the help of meddlesome courts, were now asking for even more rights and more trials: "The detainees now enjoy greater procedural protections and procedural and statutory rights to challenge their wartime detentions than any other captured enemy combatants in the history of war. Yet they claim an entitlement to more." ${ }^{17}$ The second argument was a further attempt to legitimize Congress' intent in stripping - or modifyingthe Supreme Court's habeas jurisdiction as a matter of right and replacing appeals from Combatant Status Review Tribunals (CSRTs) with review in the reliably conservative D.C. District Court. In justifying this position, the administration argued that, consistent with the WWII habeas case of Johnson $v$. Eisentrager (1950), enemy alien combatants held abroad had never been afforded habeas rights and should not now have access to them. ${ }^{18}$ This position also served as the foundation for the administration's lynchpin argument that Guantanamo Bay was not under the jurisdiction of the United States.

The final objection in the administration's Boumediene brief is one that had been levied most often by those who sought to curtail habeas access. 
The concept of "exhaustion" in habeas jurisprudence requires that the substance of habeas petitions - the actual claims of unconstitutional action against the detaining authority - must first be made and adjudicated in lower courts (either state or federal) before they can proceed to higher courts. ${ }^{19}$ While exhaustion is most commonly understood through the lens of federalism, as it requires those seeking federal review of constitutional claims to have these claims adjudicated completely on the state level before they can be heard by federal courts, the Bush administration's extension of exhaustion to the Guantanamo petitioners reflects their desire to prevent federal courts of any stripe from hearing habeas claims, instead relegating them to adjudication by military courts or tribunals that are created solely by the Executive branch. These three objections, then, have simply been superimposed onto war-time habeas cases involving enemy combatants.

\section{The Development of Executive Prerogative and the Rule of Law}

In many ways the example of habeas corpus limitations pursued by the Republican and conservative coalitions since the Warren Court could be subsumed under a larger program to increase the power of the executive's foreign affairs and war powers. For Vice President Cheney and many other advisors within the Bush administration, the power of the executive in foreign affairs and war had been eviscerated over the last three decades. ${ }^{20}$ Particularly since the passage of the War Powers Act (WPA) in 1973, the Republican coalition has made a concerted effort to reestablish what they perceive to be the proper Constitutional powers of an executive branch that is unfettered from congressional and judicial oversight in the execution of its war and foreign policy duties.

There are many in this coalition who have sought to return the executive's foreign policy and war powers to their proper constitutional footing, but most conspicuously is Vice President Cheney himself. As Gerald Ford's Chief of Staff, Cheney was part of the first post-Watergate and post-War Powers Act administration that tried to govern in the wake of the "imperial" presidency of Richard Nixon (Schlesinger 1973; Milkis and Nelson 2002). It is in the academic legal cadres of the post Warren Court coalition, then, that we see the clearest line of development in response to a perceived enervated executive. Other than Vice President Cheney, former Supreme Court nominee Robert Bork and former Deputy Assistant Attorney General in the Office of Legal Counsel, John Yoo, have presented the strongest and most consistent cases.

As President Reagan's failed Supreme Court nominee in 1987, Robert Bork serves as the Republican coalition's most intelligent and consistent representative. Bork's judicial philosophy, which was inspired both by 
Herbert Wechsler and Alexander Bickel, is still in many ways the most developed and recognizable position in conservative legal ideology (Bork 1990a, 1990b; O’Neill 2003). Aside from his Constitutional positions that relate to domestic Constitutional adjudication and theory, he has also forcefully advocated for increased presidential power war and foreign policy powers. Bork's arguments are representative of the preceding development of conservative attacks on emasculated executive war powers that eventually found their home in Bush administration with John Yoo. The salient theme that has characterized the conservative backlash both to the War Powers Act and the perceived diminution of executive power more generally is the assertion that the notion of the "rule of law," particularly the domestic rule of law precipitated by Congress, should not apply to national security issues that are within the domain of the president's war powers.

In his 1990 address to the Federalist Society, Bork laid out the contours of this approach. He argued that with respect to "the use of American troops abroad," the rule of law, "conceived as a body of legal principles declared in advance to control decisions to be made in the future," is out of place. The perception that there even could be a legal mechanism constructed to limit the executive "has debilitating effects upon our foreign policy, on the vigor of the Presidency, and the rightful place of the president in our system of government” (Bork 1990a, 695). For Bork, the problem with the idea of the "rule of law" as a limit on executive foreign policy and war powers is that it seeks to replace political checks on the executive's use of force with the strictures of legal codes. Instead, national interest, along with moral considerations, should be the guiding principles of the use of force by the executive. As he says of the United States incursions into both Grenada and Panama, "In both cases, the United States restored democracy and freedom and removed a dictatorship. That was our national interest and, so long as we think freedom and democracy are better than tyranny, it was also a highly moral action. That should be good enough" (Bork 1990a, 697). Aside from its unenforceability, then, international law precludes the executive's rightful, moral, and, most importantly, unilateral determination of national interest.

With respect to Congress' ability to regulate the executive's use of force through the War Powers Act, Bork goes even further, suggesting that it is both unworkable and unconstitutional. Because the War Powers Act seeks to define the limits of executive power as it simultaneously-and by default-defines Congress' own Constitutional powers and limitations, this simple statute passed by Congress is patently unconstitutional. If there is to be a definition of either branch's powers, it would have to be so enumerated through Constitutional amendment, not statute (Bork 1990a, 699). Moreover, the workability of the Act is belied simply by the reality of the 
executive's duty to respond to domestic attacks, particularly nuclear attacks, on the United States. The enumeration of specific instances where executive military action can or cannot be unilateral prevents the legitimate "use of force in a whole range of situations in which it has traditionally been allowed, including rescues and protection from terrorist attack" (Bork 1990a, 699). Congressional power, is, of course, not precluded by this. However, the only limits Congress can legitimately place on this power are its powers of funding. A simple refusal to continue to appropriate funds by Congress is a sufficient enough guard against wrong-headed decisions by the executive to commit troops to hostilities. Finally, Bork's overall approach to the President's constitutionally enumerated war powers is a decidedly departmentalist one (Barber and Fleming 2007; Paulson 1994). Enumerated presidential powers are first and foremost to be interpreted by the executive almost exclusively. In a final retort to the evisceration of the president's Article II powers as the result of the War Powers Act in 1973, Bork even suggested that President Richard Nixon should have appended the following note to Congress in his failed War Powers Act veto message: "Thank you very much for your essay on your understanding of my constitutional powers. When I have time, I will send you an essay on my understanding of my constitutional powers” (Bork 1990a, 700).

Aside from Robert Bork, one of the most visible proponents within the current Republican coalition's almost forty year agenda to restore the power of the Presidency is John Yoo. The architect of many of the Bush administration's legal and constitutional positions in the wake of the "War on Terror," Yoo is also a well-credentialed scholar of executive power in his own right. Even before his assent to Department of Justice's Office of Legal Counsel in the Bush administration, he was the author of numerous articles in law journals, as well as a well-received book defending an original understanding of broad, flexible, and unilateral executive war and foreign policy powers.

In significant ways, Yoo's argument is not wholly different than Bork's or even others sympathetic to executive prerogative (Rostow 1986). In both The Powers of War and Peace: The Constitution and Foreign Affairs after 9/11 (2005) and War by Other Means: An Insider's Account of the War on Terror (2006), Yoo advances three already well-developed positions that support unilateral executive war power. First is the assertion that the event of war is a political condition or state of affairs that precludes any ordinary domestic notion of the rule of law. Particularly with respect to terrorism, Yoo argues that the "War on Terror" cannot be prosecuted by governments through the lens of "crime." Instead, fighting terrorists and preventing terrorist attacks is a fundamentally political task, best achieved through military action that is freed from the domestic constraints of criminal procedure 
limitations, particularly those guaranteed in the Bill of Rights (Yoo 2006, 15). Because terrorists are not "part of the American political community," they should not benefit from the domestic protections of constitutional rights (Yoo 2006, 16). The second position he takes is that the original understanding of the president's war and foreign policy powers (combined with subsequent developments by subsequent executives) is based on a notion of flexibility in the exercise of these powers. Particularly because of the need for expedited executive response to military attacks, the framers intentionally left presidential war powers vague in order to meet the idiosyncrasies of varied crises (Yoo 2005). Finally, like Bork, Yoo also asserts that this proper understanding of executive war powers does not leave Congress powerless. Instead, because they possess the "power of the purse," Congress can simply withhold funding for continued military engagements if they disagree with the president's committal of troops. ${ }^{21}$ Yoo's party-line reading of executive war powers made the leap into policy and presidential action, as he authored or co-authored many of the Office of Legal Counsel's recommendations to President Bush, including memos on habeas jurisdiction and Guantanamo Bay; opinions upholding the use of presidential war powers more generally within the United States; and interpretations of the United States' treaty obligations with respect to the Geneva Conventions. What is most striking, then, about his analyses is their place within the already developed conservative coalition's preferred understanding of unilateral presidential war powers.

\section{Rasul, Hamdi, and Boumediene: Reconsidering the "Orthodox Innovator"}

In his groundbreaking reinterpretation of the presidency, The Politics Presidents Make, Stephen Skowronek (1997) detailed the features of "Orthodox Innovator" presidents, the most common type according to his typology. This historically situated Chief Executive is "affiliated with a resilient set of governmental commitments" and acts as "ministers to the faithful" as they articulate their coalition's "political orthodoxy." Aside from carrying the water, so to speak, of the dominant coalition which brought them to power, these presidents are often faced with particular leadership challenges that can threaten their own reelection prospects and significantly affect their coalition's legitimacy and internal efficacy (Skowronek 2008). Most of these presidents, in fact, fail to win reelection and often leave their party weaker and less resilient than when they found it. According to Skowronek, George W. Bush fits this role, but his presidency poses some problems for his account of the typical Orthodox Innovator (Skowronek 2008). Although Orthodox Innovators often fail to win reelection, 
Skowronek chalks this up to the probable effects of a war-time presidency's sympathetic affect on the electorate. What is different about this presidency, though, is its possible transformation of the party system itself. The Republican party continued to show unique loyalty to a president with extremely low approval ratings trying to govern in the milieu of a vastly unpopular war in Iraq. "Leadership by definition," then, is thus a possible new phenomenon created by Bush in the sense that parties might now take their cues directly from the president, redefining themselves according to the dictates of the executive (Skowronek 2008, 148-49). This change, according to Skowronek, is what explains the seeming unanimity within the current Republican coalition.

But is this the case, or is there evidence that in fact parts of the conservative coalition have indeed exhibited the kinds of ideological backlash and dissent that Orthodox Innovators often create? Moving beyond Skowronek's lens, which seems to disregard courts, might suggest that there is. If we accept the argument advanced in this article that the larger conservative coalition has developed and coalesced in identifiable ways around constitutional and legal ideas, then we would have to see a similar absence of dissent from the Supreme Court. Thus expanding our look to the Supreme Court would give us our answer as well as add another layer of possible convergence and divergence to presidential periodizations.

The twin programs of increased executive war powers and decreased habeas corpus access have recently come under fire by a Supreme Court that is populated by a majority of Justices appointed by Republican presidents. The Court operates within similar temporal dimensions as the president. As Robert Dahl (1957) suggested over five decades ago, the nomination process for federal courts (and especially for the Supreme Court) is likely to produce a Supreme Court that reflects the policy commitments of the dominant national coalition, thus making it less likely to exhibit counter-majoritarian tendencies (see also Keck, 2007). This might mean that certain justices, or coalitions of justices, who were nominated and appointed by previous conservative presidents, might be more likely to diverge from the actions of "Orthodox Innovators" while at the same time still remaining part of the larger coalition.

And this might in fact be what has happened to the larger conservative coalition's almost forty year push to augment executive power. The three most recent cases brought before the Supreme Court challenging the Bush administration's (and Congress') prosecution of the "War on Terror" seem to bear this point out. The particular Justices in question, who were both appointed by Republican presidents-Sandra Day O'Connor and Anthony Kennedy_each led the Court's majority opinions that significantly halted what would otherwise have been the culmination of the coalition's larger 
goals. In Hamdi v. Rumsfeld (2004), Justice O'Connor ruled that while the president was authorized to hold individuals as enemy combatants - even American citizens-they were nevertheless allowed to challenge this designated status through writs of habeas corpus. ${ }^{22}$ In Rasul v. Bush (2004), Justice Kennedy led a majority that allowed non-citizen detainees held at Guantanamo Naval base also to challenge their status through the writ of habeas corpus, severely undercutting the administration's explicit understanding of the jurisdictional reach of the federal courts. ${ }^{23}$ And in Boumediene v. Bush (2008), Kennedy again ruled against the administration-and Congress - in arguing that the Military Commissions Act (MCA) unconstitutionally suspended habeas rights. ${ }^{24}$ In each of these cases we can see a partial repudiation of the regime's salient legal and Constitutional commitments, suggesting that the more negative outcomes that are characteristic of Orthodox Innovators might have already been produced. In no small way, majorities on both the Rehnquist and Roberts Courts have rebuked both George W. Bush's and the larger Republican coalition's twin programs of decreased habeas access and increased executive war power.

While the argument presented here confirms Skowronek's argument and vindicates his notion of Orthodox Innovator presidents, it also suggests that presidential studies should incorporate more fully the temporal dynamics of legal change, particularly the political effects of any political coalition's relationship to the courts. If presidents are shaped by their place in both political and secular time, any account of that matrix must also be one that seeks to explain the dynamics of the law as well. As this article demonstrates, these dynamics are best understood by attending to the historical continuities and discontinuities of political institutions more generally as we attempt to explain patterns of political development that almost always have origins in the past.

\section{NOTES}

${ }^{1} 531$ U.S. 98 (2000).

${ }^{2}$ Cheney v. U.S. District Court 542 U.S. 367 (2004).

${ }^{3}$ But see Brandon (2005) who argues that for $80 \%$ of U.S. history we have been engaged in some sort of military conflict.

${ }^{4}$ Public Law 93-148.

${ }^{5}$ Miranda v. Arizona 384 U.S. 436 (1966); Gideon v. Wainwright 372 U.S. 335 (1963); Brown v. Board of Education 347 U.S. 483 (1954).

${ }^{6}$ Frank v. Mangum 237 U.S. 309 (1915); Moore v. Dempsey 261 U.S. 86 (1923).

${ }^{7}$ William H. Rehnquist. Statement to the Senate, Subcommittee on Constitutional Rights, Speedy Trial Act of 1971, Hearing, July 14, 1971. http://web.lexis-nexis.com/ congcomp/document?_m=b7a7b22fe6b7d4f65cf5ffe316d2e42e\&_docnum=37\&wchp= dGLzVzz-zSkSA\&_md5=adb455821d0bfed7a5d758aabd025a17. 
${ }^{8} 344$ US 443 (1953) at 537.

${ }^{9}$ William H. Rehnquist. Statement to the Senate, Subcommittee on Constitutional Rights, Speedy Trial Act of 1971.

${ }^{10}$ See, for example, Wainwright v. Sykes 433 U.S. 72 (1977) (arguing that federal habeas can be denied on adequate and independent state ground); Moore v. Sims 442 U.S. 415 (1979) (applying habeas restrictions to civil cases); and, Rose v. Mitchell 443 U.S. 545 (1979) (refusing habeas for purported grand jury discrimination).

${ }^{11}$ Letter from Smith to the Senate, March 3, 1982, quoted in Yackle (1982, 614).

${ }^{12}$ Letter from Smith to the Senate, March 3, 1982, quoted in Yackle $(1982,614)$.

${ }^{13}$ U.S. Department of Justice, May 27, 1988, "Report to the Attorney General on Federal Habeas Corpus Review of State Judgments." My account is drawn from Federman's (2004) analysis of the report.

${ }^{14} 428$ U.S. 153 (1976).

${ }^{15} 408$ U.S. 238 (1972).

${ }^{16}$ AEDPA, $\S 104$.

${ }^{17} 2006$ U.S. Briefs 1195, 12.

${ }^{18} 2006$ U.S. Briefs 1195, 19; 339 U.S. 763 (1950).

${ }^{19} 2006$ U.S. Briefs 1195, 41.

20"'Cheney Upholds Power of the Presidency,” The Washington Post, January 25, 2005 A Section.

${ }^{21}$ For an excellent critique of this position, see Silverstein (2005).

${ }^{22} 542$ U.S. 507 (2004).

${ }^{23} 542$ U.S. 466 (2004).

${ }^{24} 553$ U.S. _ (2008).

\section{REFERENCES}

Barber, James D. 1992. Presidential Character: Predicting Performance in the White House. Englewood Cliffs, NJ: Prentice Hall.

Barber, Sotirios, and James Fleming. 2007. Constitutional Interpretation: The Basic Questions. New York: Oxford University Press.

Bator, Paul M. 1963. Finality in Criminal Law and Federal Habeas Corpus for State Prisoners. Harvard Law Review 76:441.

Bickel, Alexander. 1986. The Least Dangerous Branch: The Supreme Court at the Bar of Politics. New Haven, CT: Yale University Press.

Black, Earl, and Merle Black. 2002. The Rise of the Southern Republicans. Cambridge, MA: Harvard University Press.

Bork, Robert. 1990a. Erosion of the President's Powers in Foreign Affairs. Washington University Law Quarterly 68:693.

Bork, Robert. 1990b. The Tempting of America: The Political Seduction of the Law. New York: The Free Press.

Brandon, Mark. 2005. War and the American Constitutional Order. In, The Constitution in Wartime: Beyond Alarmism and Complacency. Durham, NC: Duke University Press.

Dahl, Robert. 1957. Decision-Making in a Democracy: The Supreme Court as a National Policy Maker. Journal of Public Law 6:279.

Dudziak, Mary L. 2000. Cold War Civil Rights: Race and the Image of American Democracy. Princeton, NJ: Princeton University Press. 
Federman, Cary. 2004. Who Has the Body? The Paths to Habeas Corpus Reform. The Prison Journal 84:317.

Friendly, Henry J. 1965. The Bill of Rights as a Code of Criminal Procedure. California Law Review 53:929.

Graber, Mark A. 2005a. Counter-Stories: Maintaining and Expanding Civil Liberties in Wartime. In The Constitution in Wartime: Beyond Alarmism and Complacency. Durham, NC: Duke University Press.

Graber, Mark A. 2005b. The Right to Vote and other 'Anomalies:' Protecting and Expanding Civil Liberties in Wartime. In At War with Civil Rights and Civil Liberties. Lanham, MD: Rowman \& Littlefield.

Israel, Jerold H. 1977. Criminal Procedure, the Burger Court, and the Legacy of the Warren Court. Michigan Law Review 75:1319.

Keck, Thomas M. 2007. Party, Politics, or Judicial Independence: The Regime Politics Literature Hits the Law Schools. Law \& Social Inquiry 32:511.

Klinkner, Philip A., and Rogers M. Smith. 2002. The Unsteady March: The Rise and Decline of Racial Equality in America. Chicago: University of Chicago Press.

Milkis, Sidney M., and Michael Nelson. 2002. The American Presidency: Origins and Development, 1776-2002. Washington, DC: CQ Press.

O’Neill, Jonathan. 2003. Shaping Modern Constitutional Theory: Bickel and Bork Confront the Warren Court. The Review of Politics 65:325.

Orren, Karen, and Stephen Skowronek. 2004. The Search for American Political Development. Cambridge: Cambridge University Press.

Paulson, Michael Stokes. 1994. The Most Dangerous Branch: Executive Power to Say What the Law Is. Georgetown Law Journal 83:217.

Powe, Lucas A. Jr. 2000. The Warren Court and American Politics. Cambridge, MA: Harvard University Press.

Powell, Lewis. 1989. Commentary: Capital Punishment. Harvard Law Review 102:1035.

Rehnquist, William H. 1998. All the Laws But One: Civil Liberties in Wartime. New York: Albert A. Knopf.

Rossiter, Clinton. 2002. Constitutional Dictatorship: Crisis Government in the Modern Democracies. New York: Transaction Publishers.

Rostow, Eugene. 1986. Once More Unto the Breach: The War Powers Resolution Revisited. Valparaiso Law Review 21:1.

Schlesinger, Arthur M. 1973. The Imperial Presidency. Boston, MA: Houghton Mifflin.

Silverstein, Gordon. 1997. Imbalance of Powers: Constitutional Interpretation and the Making of American Foreign Policy. New York: Oxford University Press.

Silverstein, Gordon. 2005. Rev. of The Powers of War and Peace: The Constitution and Foreign Affairs After 9/11 by John Yoo. Constitutional Commentary 22:349.

Skowronek, Stephen. 1997. The Politics Presidents Make: Leadership from John Adams to Bill Clinton. Cambridge, MA: Harvard University Press

Skowronek, Stephen. 2008. Presidential Leadership in Political Time. Lawrence: University Press of Kansas.

Teles, Stephen M. 2008. The Rise of the Conservative Legal Movement. Princeton, NJ: Princeton University Press.

Tushent, Mark. 2005. Emergencies and the Idea of Constitutionalism. In, The Constitution in Wartime: Beyond Alarmism and Complacency. Durham, NC: Duke University Press.

Wechsler, Herbert. 1959. Toward Neutral Principles of Constitutional Law. Harvard Law Review 73:1. 
Yackle, Larry W. 1982. The Reagan Administration's Habeas Corpus Proposals. Iowa Law Review 68:609.

Yoo, John. 2005. The Powers of War and Peace: The Constitution and Foreign Affairs After 9/11. Chicago: University of Chicago Press.

Yoo, John. 2006. War by Other Means: An Insider's Account of the War on Terror. New York: Atlantic Monthly Press.

Zelizer, Julian. 2008. The Conservative Embrace of Presidential Power. Boston University Law Review 88:499. 